\title{
Central Sterile Services Department: psychosocial risks related to the prescribed organization of nursing work
}

\author{
Centro de Materiais e Esterilização: riscos psicossociais relacionados \\ à organização prescrita do trabalho da enfermagem \\ Central de Equipos y Esterilización: riesgos psicosociales relativos \\ a organización prescrita del trabajo de enfermería
}

\section{How to cite this article:} Medeiros NM, Schneider DSS, Glanzner CH. Central sterile services department: psychosocial risks related to the prescribed organization of nursing work. Rev Gaúcha Enferm. 2021;42:e20200433. doi: https://doi.org/10.1590/19831447.2021.20200433
Pesquisador autônomo. Porto Alegre, Rio Grande do Sul, Brasil.

${ }^{6}$ Hospital de Clínicas de Porto Alegre (HCPA). Porto Alegre, Rio Grande do Sul, Brasil.

- Universidade Federal do Rio Grande do Sul (UFRGS), Escola de Enfermagem, Departamento de Enfermagem Médico-Cirúrgica. Porto Alegre, Rio Grande do Sul, Brasil.

\section{Natascha Monteiro Medeiros ${ }^{\mathrm{a}}$ Daniela Silva dos Santos Schneider ${ }^{b}$ Cecília Helena Glanznerc}

\section{ABSTRACT}

Objective: The aim of this study is to investigate the characteristics of work-flow organization of the Central Sterile Services Department and analyze whether nursing workers are subject to psychosocial risks.

Method: Mixed study, carried out between November 2017 and July 2019 with nursing workers of the Department of Central Sterile Services of a university hospital. Sampling for the quantitative stage of this study consisted of 36 professionals who have filled the Prescribed Work Organization Scale form, followed by statistical analysis. Qualitative sampling was obtained through collective interview with 19 members of the nursing team.

Results: Of the 36 nursing workers, $68.3 \%$ were female, $69.4 \%$ were over 45 years of age and $75 \%$ of the professionals assessed reported as being exposed to a medium psychosocial risk with the emergence of two categories. The aspects related to pleasure at work were highlighted as being the importance of the unit, indirect patient care, professional recognition, and teamwork. The main reported suffering triggers were the lack of human resources, supplies, maintenance, communication, and the devaluation of the unit. Conclusion: The prevalence of medium psychosocial risks indicated the need for actions aiming at improving work processes. Keywords: Nursing. Occupational health. Sterilization. Nursing services.

\section{RESUMO}

Objetivo: 0 objetivo do estudo é investigar as características da organização do trabalho no Centro de Materiais e Esterilização e analisar se os trabalhadores de enfermagem estão submetidos a riscos psicossociais.

Método: Estudo misto, realizado entre novembro de 2017 e julho de 2019 com os trabalhadores de enfermagem do Centro de Materiais e Esterilização de um hospital universitário. A amostra da etapa quantitativa foi composta por 36 trabalhadores que responderam à Escala de Organização Prescrita do Trabalho e realizou-se análise estatística. A coleta das informaç̧ões qualitativas ocorreu por entrevista coletiva com 19 integrantes da equipe de enfermagem.

Resultados: Dos 36 trabalhadores,68,3\% eram do sexo feminino,69,4\% com idade superior a 45 anos e 75\% da amostra avaliou como médio o risco psicossocial, com surgimento de duas categorias. Os aspectos relacionados ao prazer no trabalho foram a importância da unidade, cuidado indireto ao paciente, reconhecimento profissional e trabalho em equipe. Os geradores de sofrimento foram a falta de recursos humanos, insumos, manutenção, comunicação e desvalorização da unidade.

Conclusão: 0 predomínio de riscos psicossociais médios indicou a necessidade de ações que visem melhorias nos processos de trabalho. Palavras-chave: Enfermagem. Saúde do trabalhador. Esterilização. Serviços de enfermagem.

\section{RESUMEN}

Objetivo: El objetivo del estudio es investigar las características de la organización del trabajo en el Central de Equipos y Esterilización y analizar si los trabajadores de enfermería están sujetos a riesgos psicosociales.

Método: Estudio mixto, realizado entre noviembre de 2017 y julio de 2019 con trabajadores de enfermería del centro de materiales y esterilización de un hospital universitario. La muestra de la etapa cuantitativa estuvo conformada por 36 trabajadores que respondieron la Escala de Organización Laboral Prescrita y se realizó análisis estadístico. La recolección de información cualitativa se produjo a través de una entrevista colectiva con 19 integrantes del equipo de enfermería.

Resultados: De los 36 trabajadores, el 68,3\% eran mujeres, el 69,4\% tenían más de 45 años y el $75 \%$ de la muestra evaluó el riesgo psicosocial como medio, con la aparición de dos categorías. Los aspectos relacionados con el placer en el trabajo fueron la importancia de la unidad, la atención indirecta al paciente, el reconocimiento profesional y el trabajo en equipo. Los generadores de sufrimiento fueron la falta de recursos humanos, suministros, mantenimiento, comunicación y devaluación de la unidad.

Conclusión: El predominio de riesgos psicosociales medios indicó la necesidad de acciones dirigidas a mejorar los procesos de trabajo. Palabras clave: Enfermería. Salud laboral. Esterilización. Servicios de enfermería. 


\section{口INTRODUCTION}

Throughout the history of mankind, work took on different meanings according to the context of the time. From the perspective of the Psychodynamics of Work, work is understood as a way of constructing the subject's identity ${ }^{(1)}$. It is an environment that enables the construction of social relationships, in which placement and social recognition take place. In this way, work is configured as a central aspect in the mental health of individuals, and can be understood both as a source of pleasure and achievement, by mobilizing subjectivity and allowing the use of intelligence and creativity, as a reason for suffering, when there is frustration and alienation of the worker ${ }^{(2)}$.

At the same time that the labor activity assumes such an important position in the individual's life, it can also offer the worker risks of illness. The World Health Organization and the International Labor Organization define psychosocial risks as interactions with different aspects of work that can, through the worker's perceptions and experiences, influence their performance, satisfaction, and health. Thus, psychosocial risks are aspects related to work capable of causing damage to the mental and physical health of workers ${ }^{(3)}$.

Psychosocial risks can be divided into two groups: those related to the content of the work and those related to the work context. The work content includes aspects such as work pace, task organization model, working hours and adequacy of the environment and equipment used, including maintenance and availability of supplies. The work context, on the other hand, encompasses aspects such as organizational culture, interpersonal relationships, participation in decisions and control of work, and the interface between work and home ${ }^{(2-3)}$.

An aspect that directly contributes to the development of psychosocial risks is the how work is imposed on the worker ${ }^{(2-3)}$, as well as the management style adopted and the relationship with suffering, which may result in physical, psychological or social. The prescribed organization of work is the conjuncture in which the work activity will take place. In this scenario, the instruments used to perform the work, protocols, speed and time of execution of each task, operational norms, division of tasks and responsibilities, as well as the establishment of hierarchy and supervision ${ }^{(2)}$ are included. However, in daily practice, the prescribed organization of work is not able to plan the management of unexpected situations, which distances the real work from the prescribed work, causing a gap that will be experienced by the worker as an opportunity to overcome and pleasure, or else, as a suffering ${ }^{(1-2)}$. In this sense, suffering precedes psychosocial risks and the strategies adopted to face them are essential in preventing illnesses, being dependent on the organization of work. This is how the prescribed organization of work directly influences psychosocial risks, being an important facet to consider in worker health ${ }^{(2)}$.

For the approximation of real and prescribed work, it is essential that the assessment of the environment is carried out by the workers themselves, which constitutes a challenge for leaders and managers ${ }^{(1)}$. Consequently, this assessment of the environment also contributes to the preservation of health and well-being at work, as it allows the planning of actions focused on the needs indicated by the workers ${ }^{(2)}$. It is in this context that emerge scales capable of assessing different aspects of work. The Prescribed Work Organization scale (PWOS) makes it possible to assess the representations that workers have of the elements that make up the prescribed organization of their work ${ }^{(2)}$.

With regard to health-related professions, nursing corresponds to the largest professional category working in health services in the country ${ }^{(4)}$. In the hospital environment, it can be said that the nursing work process encompasses activities such as direct and indirect patient care, resource management and teaching and research activities ${ }^{(5)}$. The hospital organization aims to care for patients with increasingly critical health conditions ${ }^{(6)}$, with nursing being fundamental for the functioning of these institutions, as its main purpose is the planning and execution of care.

Technological advances have led to the evolution of procedures, especially anesthetic-surgical ones, providing opportunities for the emergence of areas in which increasingly specific nursing knowledge is required ${ }^{(7)}$, such as the Central Sterile Services Department (CSSD).

The CSSD is conceptualized as a functional unit in which health products (HP) are processed with the objective of serving health services. Its activities include the reception, cleaning, inspection, preparation, disinfection, sterilization and storage of health items ${ }^{(8)}$. The work process at the CSSD is characterized by the specificity of the activities developed, which requires continuous acquisition of knowledge and skills that meet the technological evolution of HP. It also stands out for its indirect patient care, as it guarantees the quality and safety of HP that will be used in surgical, outpatient and inpatient areas ${ }^{(9)}$.

When it comes to psychosocial risks faced by nursing in various fields of activity, it can be highlighted the lack of equipment maintenance, relationship problems between workers, communication problems, shortage of human resources, accelerated work pace, increased workload and inadequate physical environment ${ }^{(6-10)}$. In the CSSD, studies show that the main factors that put the health and safety of workers at risk are contact with chemical products and 
biological agents, repetitive physical effort and staying in an environment with high temperature and noise ${ }^{(11-12)}$.

Based on the precepts described and the guiding question: does work at the CSSD offer psychosocial risks to its workers? The objective of this study was to investigate the characteristics of work organization at the Central Sterile Services Department and analyze whether nursing workers are subject to psychosocial risks.

\section{METHOD}

This is a cross-sectional and descriptive study, in which the sequential mixed method was used. Initially, a large volume of primary numerical data was collected, which had a deeper understanding through qualitative techniques. The combination of data was done by connection, with the quantitative approach superimposed on the qualitative ${ }^{(13)}$. Therefore, the Psychodynamics of Work was used as a theoretical and methodological framework in the application of the quantitative and qualitative stages ${ }^{(1-2)}$.

The study population consisted by 83 workers, including nurses, technicians and nursing assistants working in the CSSD of a large public and university hospital in a Brazilian capital. The sample consisted by 36 workers, randomly selected. It was possible to estimate the psychosocial risks related to the prescribed organization of work with an absolute margin of error of $17 \%$ for a confidence level of $95 \%$.

In the quantitative stage, the inclusion criteria were: having an effective employment relationship with the hospital and acting as a nurse, technician and/or nursing assistant, having more than six months of experience in the Central Sterile Services Department in the morning, afternoon, night shifts (in the department there are three nights, called Night I, II and III), intermediate and weekend. These last two grouped with the other nomenclature. Exclusion criteria were: having a temporary contract, being away, on vacation or on leave for any reason at the time of data collection, having less than six months of time in the current function and sector.

In the qualitative stage, all nursing workers who agreed to participate in the collective interview and who were present at the unit at the previously published time were included, this is a convenience sampling.

Quantitative data collection was carried out between November 2017 and January 2018. The collection of qualitative information was carried out in July 2019. The instrument used for the collection of quantitative data was the Prescribed Work Organization scale (PWOS) ${ }^{(2)}$. The PWOS is composed of 19 positive sentences that assess the organization of work, working conditions and socio-professional relationships. These 19 statements were assessed by the worker using a five-point Likert scale (never, rarely, sometimes, frequently and always). The mean of the scores of each statement was classified according to the following parameters: between 1 and 2.29 - high psychosocial risk; between 2.3 and 3.69 - medium psychosocial risk and; between 3.7 and 5 - low psychosocial risk. The standard deviation considered the midpoint, that is, 3 of the Likert-type frequency scale. In addition to the PWOS, the workers also answered a sociodemographic questionnaire that aimed to obtain information about habits, health conditions and absence from work.

The data were organized in a spreadsheet and statistically analyzed using the Statistical Package for the Social Sciences software (SPSS 22.0) using measures of central tendency (simple frequency, relative frequency, absolute frequency, mean or median, maximum and minimum) and dispersion measures (standard deviation and quartiles). Analysis of variance (ANOVA) was used for comparison between groups and the T-Test was used to identify the significance of differences $(p<0.05)$.

The interview was previously scheduled and published through the distribution of posters at the Central Sterile Services Department. 19 workers participated, one being a nurse and 18 nursing technicians and assistants.

The interview was conducted at the CSSD and lasted approximately 2 hours ( 1 hour for data presentation and 1 hour for the actual interview), without prejudice to the work carried out by the department's previous organization. Initially, the quantitative data statistically treated were presented by using an audiovisual resource. Afterwards, the workers were invited to talk about their perception in relation to the working conditions at the CSSD, for that, the following questions were asked: 1) What brings more satisfaction when performing your work? 2) What are the main difficulties in your daily work? 3) What do you do to deal with them?

The interview was conducted by a researcher and two others took the field notes. The speeches of the participants were audio-recorded and transcribed in full, ensuring the veracity of the data. The collective interview ended after validation of the information and data saturation, which occurred by the repetition of the themes.

Thematic content analysis technique was used to treat the qualitative information obtained an for that three steps were followed: pre-analysis of the content obtained, material exploration and categorization of the speeches, and, finally, data processing and interpretation of the qualitative data obtained ${ }^{(14)}$. The analysis and discussion of the quanti-qualitative results obtained were carried out in the light of the Psychodynamics of Work proposed by Dejours ${ }^{(1-2)}$, in which two thematic categories emerged: pleasure in the work of the CSSD and work-related suffering at the CSSD. 
This study was approved by the Research Ethics Committee of the institution, under CAAE No: 65993517.9.0000.5327. The ethical precepts contained in Resolution 466/2012 were followed. All participants signed the Informed Consent Form in duplicate in the two stages of the research. To guarantee the anonymity of the participants in the presentation of the speeches, the coding "Nur" was used for the nurses' statements and the coding "NT"for the nursing technicians, followed by the number that indicates the order of speech of the worker in the interview.

\section{QRESULTS}

From the 36 workers of the nursing team of the CSSD who responded to the PWOS, most were female, representing $63.8 \%(n=23)$ of the sample, and over 45 years of age $(n=25$, $69.4 \%$ ). The predominant age group among workers was between 46 and 55 years ( $n=13,37.1 \%)$, followed by workers aged between 36 and 45 years $(n=9,25.7 \%)$ and by workers over 60 years old $(n=9,25.7 \%)$, only four workers were 35 years old or less (11.4\%). Nursing assistants and technicians comprised the majority of the sample $(n=31,86.1 \%)$, followed by nurses $(n=5,13.9 \%)$.

Regarding the length of experience, $36.1 \%(n=13)$ of the workers had been hired for more than 20 years and 33.3\% $(n=12)$ of the workers had worked for 10 to 20 years. Considering work at the CSSD, 34.3\% ( $n=12$ ) of the workers were between 10 and 20 years in the position and 31.4\% $(n=11)$ had been in that position for more than 20 years, which characterizes an experienced sample in the unit.

As for health-related habits, most workers ( $n=35,97.2 \%$ ) had undergone the medical examination in the last year, $11.1 \%(n=4)$ reported smoking, $25.7 \%(n=9)$ reported that they did not sleep well and $38.9 \%$ ( $n=14$ ) reported that they do not regularly perform physical activities.

Table 1 shows the items that comprise the Prescribed Work Organization Scale, as well as their respective mean scores (Mean), standard deviation (SD) and the level of psychosocial risk they represent.

For $75 \%$ ( $n=27$ ) of the workers, the mean score of their responses to the 19 items in the table indicated an average psychosocial risk linked to the prescribed work organization. For the rest of the workers $(n=9,25 \%)$, the mean score of the items indicated low psychosocial risk. No worker had a total mean on the suggestive scale of high work-related psychosocial risk.

Looking for a better understanding of both the work processes and the psychosocial risks experienced, the data were validated and discussed with the nursing team of the CSSD during the interview. In the reports, the workers mentioned both their identification and pleasure with the work performed, as well as pointing out aspects related to the organization of work that make daily work difficult, triggering suffering. From the analysis of the reports in the light of the Psychodynamics of Work framework ${ }^{(1-2)}$, two thematic categories are presented: pleasure in the work of the Central Sterile Services Department and work-related suffering at the Central Sterile Services Department.

\section{Pleasure in the work of the Central Sterile Services Department}

In this category are described the main reasons for pleasure mentioned by the CSSD workers: identification of the importance of the unit for the hospital, indirect care for the patient, recognition of their work, teamwork and confidence in their personal skills used in performing the tasks.

\section{Mysatisfaction in working at the CSSD is an achievement in working in the place where I consider to be the heart of a hospital [...] if the CSSD doesn't work, the hospital doesn't work, nowhere inside here. [...] I really value what I do, and I really like what I do. (NT6) \\ What gives me the most satisfaction when doing my job is knowing the completion it will cause. Our work here at the CSSD, whether it is a bladder catheterization package, I know it will be very useful at the end of the process, which is to perform a bladder catheterization in the patient who has incontinence [...] this is what brings mesatisfaction, knowing that I started and I know where it will end. (NT3)}

In the statements above, there is an understanding of the importance of work at the CSSD, which constitutes a key aspect for the functioning of the health institution. And through it, indirect care to the patient is performed, providing pleasure to workers when they identify with their activities.

Recognition of their work by colleagues and supervisors is also presented as a beneficial aspect for workers, who express their desire to be encouraged:

That the recognition of the work, the encouragement, even a pat on the back and a compliment, I think this is very important, because it makes you commit more and more and give a good result. (NT1)

Another beneficial aspect pointed out about work at the CSSD concerns the worker's assessment of teamwork, which contributes to their self-confidence in their ability to perform the proposed tasks. 
Table 1 - Mean, standard deviation and risk indication of the scores of the Prescribed Work Organization Scale items answered by CSSD workers. Porto Alegre - 2017-2018 $(n=36)$

\begin{tabular}{|c|c|c|c|c|}
\hline Item & Statement & Mean & SD & Risk \\
\hline 1 & The number of workers is sufficient to perform the tasks. & 2.75 & 1.00 & Medium \\
\hline 2 & There are enough work resources to perform the tasks. & 3.08 & 0.81 & Medium \\
\hline 3 & $\begin{array}{l}\text { The physical space available to perform the work } \\
\text { is adequate. }\end{array}$ & 2.72 & 1.14 & Medium \\
\hline 4 & Equipment is adequate to perform the tasks. & 3.29 & 1.05 & Medium \\
\hline 5 & There is clarity in the definition of tasks. & 3.75 & 0.73 & Low \\
\hline 6 & There is fairness in the distribution of tasks. & 3.21 & 0.88 & Medium \\
\hline 7 & Employees participate in work decisions. & 3.08 & 0.84 & Medium \\
\hline 8 & $\begin{array}{l}\text { Communication between head and subordinate } \\
\text { is adequate. }\end{array}$ & 3.51 & 0.85 & Medium \\
\hline 9 & I have the autonomy to perform the tasks as I think best. & 3.36 & 0.99 & Medium \\
\hline 10 & There is quality in communication between employees. & 3.47 & 0.88 & Medium \\
\hline 11 & The information I need to perform my tasks is clear. & 3.72 & 0.82 & Low \\
\hline 12 & The work pace is adequate. & 3.08 & 0.97 & Medium \\
\hline 13 & The deadlines to perform the tasks are flexible. & 3.25 & 0.84 & Medium \\
\hline 14 & $\begin{array}{l}\text { The evaluation of my work includes aspects beyond } \\
\text { my production. }\end{array}$ & 3.97 & 0.97 & Low \\
\hline 15 & There is flexibility in the rules to perform the tasks. & 3.34 & 0.87 & Medium \\
\hline 16 & $\begin{array}{l}\text { The guidelines given to me to perform the tasks are } \\
\text { consistent with each other. }\end{array}$ & 3.74 & 0.82 & Low \\
\hline 17 & The tasks I perform in my work are varied. & 3.89 & 0.80 & Low \\
\hline 18 & I have the freedom to express my opinion about my work. & 3.53 & 0.97 & Medium \\
\hline 19 & $\begin{array}{l}\text { It has adequate conditions to achieve the expected results } \\
\text { of my work. }\end{array}$ & 3.86 & 0.87 & Low \\
\hline
\end{tabular}

Source: Research data, 2017-2018 
We get help from each other. You know? Like, everyone helps each other. So I think I feel good about it too. We live a lot here with people, we are here every day. So the relationship is very important. (NT4)

This self-confidence in performing the tasks is described in item 19, which obtained a score of 3.89 (low psychosocial risk) and concerns the necessary conditions to achieve the expected results for the proposed tasks. These results indicate that workers recognize their ability to fulfill their tasks and feel satisfied with their assessments, as represented in the speech below:

I was very well received, and it was very easy for me to perform all the tasks that have been proposed so far. And I'm really happy. (NT5)

Despite feeling satisfied with their professional activities at the CSSD, workers also pointed out aspects that make their daily work difficult, triggering work-related suffering.

\section{Work-related suffering at the Central Sterile Services Department}

In this category it is presented the greatest causes of suffering described by nursing workers: lack of human resources to perform the work, lack of supplies, problems in equipment maintenance, communication failures and the perception of devaluation of the work performed at the CSSD by colleagues from other units.

One of the scale items with the highest psychosocial risk was 1, which deals with the adequacy of the number of employees to perform the tasks, with a score of 2.75 (medium psychosocial risk). The percentage of workers who went on leave in the last year was $44.4 \%(n=36)$, of which $5.6 \%$ $(n=36)$ went through three or more leaves. This picture is evidenced in the speech:

Because always someone who gets hurt or has a medical statement because of work, because it's heavy, it's not a simple thing. [...] It is contact with a lot of chemical products too. (Nur)

A statistically positive relationship was found between a greater number of leaves and a greater psychosocial risk related to the prescribed work organization. This higher psychosocial risk is demonstrated through a lower score on the scale. Considering the last year and dividing the workers into three groups: workers who did not leave, workers who took leave of up to three times and workers who had more than three leaves, it was identified that the first group had an mean scale score of 3.57, the second group had a score of 3.25 and the third of 2.73 . In other words, there was a statistical difference between the scores of the first and second groups ( $p=0.044)$ and between the scores of the first and third groups of workers $(p=0.015)$. No statistically significant difference was found between the second and third group of workers. Thus, it is evident that a greater number of leaves is linked to a lower score on the scale and, therefore, to greater psychosocial risks experienced and related to the prescribed work organization.

Other reported difficulties are linked to the physical conditions of work, which, in addition to the physical space, are made up of structural elements that enable the performance of tasks, such as the provision of supplies, the quality and maintenance of the machinery used. The item on the scale with the lowest score $(2.72$, medium psychosocial risk) was 3 , which concerns the physical space available to perform the work. Item 4, which deals with the adequacy of equipment to perform the tasks, had a score of 3.29 (medium psychosocial risk). These adversities found in the physical working conditions are clear in the speeches of workers, which emphasize how the maintenance of equipment directly affects the organization of work.

I say that the main difficulty is to miss material to perform the work or that there is a broken machine, which does not make things going on. (NT7)

The lack of materials, treated by item 2 of the PWOS, obtained an medium risk score (3.08), being identified as another obstacle in the performance of the tasks. The temporary unavailability of equipment under maintenance impacts the work process, as when the equipment returns to operation, changes in the work pace are necessary so that the shift tasks can be completed on time. Item 12, which talks about the adequacy of the work pace, had a score of 3.08, being considered a medium risk.

The lack of equipment and supplies needed to perform the tasks translates into a situation not foreseen in the organization of work for the CSSD. This breakdown in the organization, combined with the demands, end up triggering suffering in the worker.

By the end of the week three autoclaves were out of order. One small one working, the smallest I had, and a medium one. [...] to put it up and running took more than one work shift. Practically all morning it didn't work, all afternoon, it only worked at dawn. (NT8) 
The equipment is broken all the time, stopped, this has made our commitment to the work very difficult. You arrive, start doing it, and in a little while everything stops! Phone ringing all the time, where's the material? Why didn't it come down? It gives the impression to outsiders that we are not producing. But It's just beyond our purview. (NT3)

I think that currently we have had a much higher workload charge and this lack of maintenance of equipment and supplies to carry out the work, which has increased, has decreased. Then we've been feeling pretty lost. (NT3)

In addition to physical working conditions, the PWOS also assesses communication between workers and socio-professional relationships. Items considered as important as the equipment, as evidenced in the speech:

It's no use bringing us first world equipment, new material, etc and etc, if the communication that is taking place is not improved. (NT3)

This professional technique that we have to know is important, but it is also very important to have people who help us to develop this work more safely. (NT7)

Effective communication between workers is extremely important, both for the performance of work and for the maintenance of individual and laboral well-being. Item 10, which discusses communication between employees, obtained a score of 3.47 (medium risk). However, the greatest communication difficulties pointed out by CSSD workers concern other units, especially the Surgical Ward (SW). Non-assertive communication and lack of knowledge about work processes between the units generate negative impacts, leading to an increase in psychosocial risk and worker wear.

We had already talked about having an integration with the block's technicians, for them to come to know the CSSD, for them to see how the CSSD works. Because most don't know, they have no idea. (NT10)

They keep saying different names, they don't know how to request the material [...] You arrive in an environment full of problems, unmotivated people... I think everyone is here because they like it, otherwise they'd already picked up the bag and had already left, because it's not easy. (Nur) Several times I have stayed back there, and the materials disappear, then we look for it, and the material is down there. But no one calls to say it's there, to give a feedback. (NT11)
Also, in relation to communication, item 8 obtained a score of 3.5, which indicates that communication between heads and subordinates represents a medium psychosocial risk. This item includes the charges made, which also reflects on the worker's feeling of discontent in face of the adversities experienced in daily work.

Why do you talk so much about the block? It's what charges us the most, right? I always use an example like this: ifyou send a package with an altered date, the nurse there already takes it and says look here [...] Everything stops here at the CSSD, they have a meeting [...] When a scalpel blade on a handle, ifyou complain, die here. (NT8)

Through the speeches, it was also possible to identify the importance of aligning the work-flow organization in preventing errors, as well as the need for training and especially for better communication between peers.

The error appears and they want to crucify the nurse, the technician. Nobody wants to see the process, why it happened. It's a machine that doesn't work, it's a whole manual process in which I depend a lot on the person who is there, on her knowing well what she's doing [...] but, it's an error that happened since receiving, that at sometimes we do things that are not even standardized [...] But then if the error appears, no one asks if everyone is prepared, how is the training going. (Nur)

Regarding the nurse's speech, item 11 obtained a score of 3.72 (low psychosocial risk) indicating that there is some clarity in the information needed to perform the tasks. The institution to which the studied CSSD belongs has a commission that seeks to create and improve operational protocols, which are widely disseminated.

Another factor of suffering for CSSD workers is the understanding that the department is an area for workers with difficulties or restrictions, which is shown below:

The CSSD is seen as an unimportant thing, where the technicians don't have skills and that's why they are at the CSSD. Is the person unable to work? Put him/her in the CSSD. Can't the person work in a sector anymore? Go to the CSSD, got it? (NT5)

The perception described in the report above that CSSD workers are undervalued in relation to workers from other units is a trigger factor of suffering, as although the CSSD is a specialized sector, this is little recognized. 


\section{DISCUSSION}

Brazilian nursing has a predominantly female profile, according to a survey carried out in $2017,85.1 \%$ of the professionals who make up the nursing teams are female(4). This trend is maintained when it comes to CSSD workers, in which the female presence varies between $54.1 \%(15)$ and $93.75 \%{ }^{(9)}$ in the literature. Regarding the age of workers, the predominant age group is between 25 and 35 years old ${ }^{(16)}$. In the studies consulted, most CSSD workers work in the area between one and 10 years, with percentages ranging between $43.75 \%{ }^{(9)}$ and $64.71 \%{ }^{(16)}$.

In relation to the 19 items assessed by the PWOS, none had a mean indicative of high psychosocial risk and 6 of the analyzed items had low psychosocial risks, which is a positive result demonstrated by the data. Aspects related to the organization of work identified as low psychosocial risks must be maintained and enhanced in the work environment. However, the presence of 13 items indicative of medium psychosocial risks requires attention from managers, as they indicate an extreme situation and demand short or medium-term interventions aimed at mitigating or eliminating the causes of these risks ${ }^{(2)}$.

As seen, the workspace is experienced as both a place of pleasure and suffering. The main reason for satisfaction of CSSD workers was the understanding of the strategic importance of the unit in the functioning of health institutions. The CSSD is the unit responsible for performing the reception, cleaning, disinfection, sterilization, microbiological tests, storage and distribution of health products (HP) to all units that provide direct care to patients ${ }^{(9)}$.

Another factor of satisfaction for workers was the indirect care for the patient, as it is in the CSSD that the care process begins by ensuring the quality of the processed material, avoiding the occurrence of adverse events such as infections related to health care. Thus, the efficiency and quality of the sector's functioning reflect directly on the care provided to patients ${ }^{(9)}$, providing workers with a feeling of recognition of the work performed.

Mutual cooperation between workers was also pointed out as an aspect that facilitates work and promotes health, reflecting the importance of teamwork. The union of skills of different workers towards a desired goal, respect and encouragement of creativity in the labor environment are considered reasons for satisfaction (11), providing confidence to workers in performing specialized activities.

Despite the workers' satisfaction, some aspects were identified as generators of suffering in daily work. When the experience of real work get away from the prescribed work, such as on occasions when resources or equipment are lacking or when there are difficulties of communication, the worker experiences a gap, a situation that was not foreseen for in their work standards, which can become both an opportunity for overcoming and pleasure, as a source of suffering ${ }^{(2)}$. Thus, the development of suffering is not only conditioned to working conditions, but is also related to the worker's ability to adapt to psychological demands that seem abusive or unsurpassing. Influencing the psychic dimension of the worker, suffering affects the creative capacity and makes concentration difficult, which reduces the ability to elaborate solutions and reflects in the reduction of satisfaction in working and being useful. The development of diseases such as migraine, hypertension and gastric ulcers can be triggered by the repercussion of psychosocial exhaustion, which alerts to the need for actions aimed at promoting the health of workers ${ }^{(11)}$.

The aspects of work identified by workers as triggers of suffering and, therefore, as greater psychosocial risks, are related to the lack of human resources and necessary materials to perform the work. The insufficient number of workers results in an overload in the distribution of tasks, leading to physical and mental exhaustion of the team and a consequent drop in performance ${ }^{(11)}$.

Factors capable of triggering stress in workers are included in psychosocial risks, which comprise physical, psychological and social dimensions of the organization of work ${ }^{(3)}$. Thus, the existence of work-related aspects that generate a risk of physical harm to workers are also evaluated within the psychosocial risks. The consequences of psychosocial risks include increased absenteeism and presenteeism, drops in worker productivity and increased economic costs ${ }^{(3)}$.

The lack of materials and the limitations of physical resources also restrict the work process ${ }^{(9)}$. The availability of materials is something so essential for the worker that obtaining supplies to perform the prescribed tasks came to be pointed out as a factor of satisfaction by workers at the CSSD of a university hospital ${ }^{(11)}$. However, it is highlighted that according to the Resolution of the Collegiate Board (RCB) No. 63 of 2011, it is the duty of health establishments to provide resources and infrastructure that enable workers to perform their tasks, as well as training before the start of activities and permanently and continuously. These trainings should include data on potential risks to workers' health, use of personal protective equipment and measures to minimize exposure to harmful agents ${ }^{(17)}$.

Other health and safety risks reported by workers are related to contact with chemical products such as cleaning and disinfection agents, contact with potentially contaminating biological agents resulting from dirty materials, physical effort, postural discomfort and work overload ${ }^{(12)}$. The literature states that the characteristics of the work in the area 
cause an overload in carrying weight, as materials such as surgical instrument boxes are heavy and the handling of these materials is constant. If performed with inadequate postures, activities that demand intense physical strength and repetitive effort can lead to the development or aggravations of musculoskeletal injuries ${ }^{(11)}$.

In relation to the physical space of the CSSD, critical aspects such as the thermal environment and noise production stand out. Heat is widely used in cleaning, disinfecting and sterilizing materials. Various equipment, such as autoclaves and ultrasonic washers, are considered strong heat generators, which raise the temperature of the environment and cause discomfort to workers. The equipment used in the CSSD also produces noise at high levels, which can cause damage to health in the short, medium or long term ${ }^{(12)}$.

Another factor that triggers suffering mentioned by the workers concerns communication difficulties. Effective communication encompasses the ability to transmit, receive and interpret information in a clear and respectful way, using objective and non-accusatory language ${ }^{(18)}$. Communication is essential for care, constituting the foundation of interpersonal relationships and providing opportunities for teamwork, as it organizes individual skills into actions that result in a common goal.

When it comes to the Surgical Center, the need for communication is intensified, as the work processes in these units are complex and interdisciplinary. Failures in oral or written communication can result in mistakes, leading to adverse events for workers and patients. However, when effective, communication characterizes a great management tool, acting as a safety factor in anesthetic-surgical procedures ${ }^{(19)}$. Thus, effective communication between workers and the establishment of work flows between the CSSD and other units is essential, not only for the balance and health of the labor environment, but also for patient safety ${ }^{(18-19)}$.

The perception of devaluation of other sectors in relation to the work performed at the CSSD is configured as a source of suffering commonly portrayed ${ }^{(0,11,20)}$. Although workers recognize its importance for the functioning of health services, they realize that the CSSD is often referred to as a place of lesser complexity, with several factors contributing to this stigma. Among them, the characterization of work as indirect patient care can be highlighted; the presentation of similarities with housework, historically undervalued; performing tasks in a closed area, isolated from other units; the history of relocation of employees with health problems and, finally, the reduced emphasis on professional training ${ }^{(20)}$.

It is believed that a better understanding of work processes in the area could contribute to the recognition and appreciation of nursing work in the CSSD and mitigate the dissatisfaction that CSSD workers feel in relation to the lack of knowledge that other units have about the sector. This understanding also contributes to patient and worker safety, since alignment in the tasks flow and effective communication are essential for the adjustment and proper functioning of standardized operating protocols. It is considered as possible limitations of this study the data collection period, as well as the performance in a single CSSD and in a single context.

\section{CONCLUSION}

The study allowed us to know the characteristics of the work of the nursing team at the CSSD, as well as the psychosocial risks related to the prescribed work organization, identifying the experiences of pleasure and suffering in the labor space.

The concern with workers' health needs to play a fundamental role in institutions, which must aim at the assessment of the causes of illness, intervening before curative actions are needed. The identification of positive or negative aspects of work organization helps managers to identify which beneficial aspects should be reinforced in daily life and which aspects need intervention, preventing workers' exposure to psychosocial risks and illness. It is up to the workers to participate in the identification of psychosocial risks and in establishing priorities for intervention, in addition to supporting the implementation of collective preventive measures and awareness-raising actions.

Considering the importance of the theme and its reflections on daily work, it is encouraged further research in the area. The Central Sterile Services Department is characterized by a dynamic unit that is in constant technological evolution, therefore, specialized knowledge is able to have a unique impact on patient care and on the organization of the work of the health institution.

\section{REFERENCES}

1. Duarte FS, Mendes AMB. Da escravidão à servidão voluntária: perspectivas para a clínica psicodinâmica do trabalho no Brasil. Farol. 2015 [cited 2020 Out 29];2(3):71-134. Available from: https://revistas.face.ufmg.br/index.php/farol/ article/view/2579

2. Facas EP. Protocolo de avaliação dos riscos psicossociais no trabalho - contribuições da psicodinâmica do trabalho [Tese]. Brasilia: Instituto de Psicologia. Universidade de Brasilia; 2013. [cited 2020 Out 29]. Available from: https://repositorio.unb. br/handle/10482/15420

3. Forastieri V. Prevention of psychosocial risks and work-related stress. International Journal of Labour Research. 2016 [cited 2020 Out 29];8(1-2):11-33. Available from:https://www.llo.org/wcmsp5/groups/public/---ed_dialogue/---actrav/ documents/publication/wcms_551796.pdf

4. Conselho Federal de Enfermagem; Fundação Oswaldo Cruz. Perfil da Enfermagem no Brasil: relatório final. Rio de Janeiro: Fiocruz; 2017. [cited 2020 Out 29]. Available from: http://www.cofen.gov.br/perfilenfermagem/pdfs/relatoriofinal.pdf 
5. Ferreira VHS, Teixeira VM, Giacomini MA, Alves LR, Gleriano JS, Chaves LDP. Contributions and challenges of hospital nursing management: scientific evidence. Rev Gaúcha Enferm. 2019;40: e20180291. doi: https://doi. org/10.1590/1983-1447.2019.20180291

6. Scozzafave MCS, Leal LA, Soares MI, Henriques SH. Psychosocial risks related to the nurse in the psychiatric hospital and management strategies. Rev Bras Enferm. 2019;72(4):834-40. doi:https://doi.org/10.1590/0034-7167-2017-0311

7. Martins RC, Trevilato DD, Jost MT, Caregnato RCA. Nursing performance in robotic surgeries: integrative review. Rev Bras Enferm. 2019;72(3):795-800. doi: https:// doi.org/10.1590/0034-7167-2018-0426

8. Ministério da Saúde (BR). Agência Nacional de Vigilância Sanitária. Resolução ñ.15, de 15 de março de 2012. Dispõe sobre requisitos de boas práticas para 0 processamento de produtos para saúde e dá outras providências. Diário Oficial União; 2012. [cited 2020 Out 29] mar 19;149(54 Seção 1):43-46. Available from: https://pesquisa.in.gov.br/imprensa/jsp/visualiza/index. jsp?data $=19 / 03 / 2012 \&$ jornal $=1$ \&pagina $=46 \&$ totalArquivos $=128$

9. Bugs TV, Rigo DFH, Bohrer CD, Borges F, Marques LGS, Vasconcelos RO, et al. Profile of the nursing staff and perceptions of the work performed in a materials center. Rev Min Enferm. 2017;21:e-996. doi: https://doi.org/10.5935/1415-2762.20170006

10. Duarte MLC, Glanzner CH, Pereira LP. Work in hospital emergency: suffering and defensive nursing care strategies. Rev Gaúcha Enferm. 2018;39: e2017-0255. doi: https://doi.org/10.1590/1983-1447.2018.2017-0255

11. Costa CCP, Souza NVDO, Silva PAS, Oliveira EB, Vieira MLC. 0 trabalho na central de material: repercussões para a saúde dos trabalhadores de enfermagem. Rev Enferm UERJ. 2015;23(4):533-39. doi: https://doi.org/10.12957/ reuerj.2015.15934

12. Mendes C, Sousa M, Lança AC, Ferreira A, Paixão S. Riscos ocupacionais nas centrais de esterilização hospitalares. In: Neves MC, Camarada M, Leal A, Silva M, Onofre C, Morgado H, et al, editores. Vertentes e desafios da segurança. 8. ed. Leiria: ASVDS; 2018. p. 135-40. [cited 2020 Out 29]. Available from: http://hdl. handle.net/10400.26/28167
13. Oliveira JLC, Magalhães AMM, Matsuda LM. Mixed methods in nursing research: application possibilities according to Creswell. Texto Contexto Enferm. 2018;27(2): e0560017. doi: https://doi.org/10.1590/0104-070720180000560017

14. Minayo MCS, Guerriero ICZ. Reflexividade como éthos da pesquisa qualitativa. Ciênc Saúde Coletiva. 2014;19(4):1103-12. doi: https://doi. org/10.1590/1413-81232014194.18912013

15. Nazareth JCF, Almeida Neto OP, Silva MR, Rodrigues LR, Pedrosa LAK. Quality of life related work of nursing professionals in sterilization material center. Biosci J. 2018 [cited 2020 Out 29];34(4):1083-92. Available from: http://www.seer.ufu. br/index.php/biosciencejournal/article/view/38940/22685

16. Costa CCP, Souza NVD0, Pires AS. Profile of workers of a material and sterilization: an analysis of social and professional characteristics. J Res Fundam Care Online. 2016;8(1):3633-45. doi: https://doi.org/10.9789/2175-5361.2016. v8i1.3633-3645

17. Ministério da Saúde (BR). Agência Nacional de Vigilância Sanitária. Resolução $n^{0} .63$, de 25 de novembro de 2011. Dispõe sobre os Requisitos de Boas Práticas de Funcionamento para os Serviços de Saúde. Diário Oficial União; 2011 nov 28. 148(227 Seção 1):44-46. Available from: https://pesquisa.in.gov.br/imprensa/jsp/visualiza/ index.jsp?data $=28 / 11 / 2011 \&$ jornal $=1 \&$ pagina $=44 \&$ totalArquivos=128 [cited 2020 Out 29].

18. Moreira FTLS, Callou RCM, Albuquerque GA, Oliveira RM. Effective communication strategies for managing disruptive behaviors and promoting patient safety. Rev Gaúcha Enferm. 2019;40(esp):e20180308. doi: https://doi. org/10.1590/1983-1447.2019.20180308

19. Martins FZ, Dall'Agnol CM. Surgical center: challenges and strategies for nurses in managerial activities. Rev Gaúcha Enferm. 2016;37(4):e56945. doi: https:// doi.org/10.1590/1983-1447.2016.04.56945

20. Spagnol CA, Colem NCS, Oliveira BKS, Pereira ADS, Silva RHL, Mussel IC, et al. Hot footbath therapy: taking care of the nursing at the centre for material and sterilization. Rev SOBECC. 2015;20(1):45-52. doi: https://doi.org/10.5327/ Z1414-4425201500010007 


\section{- Authorship contribution:}

Conceptualization: Natascha Monteiro Medeiros.

Data curation: Natascha Monteiro Medeiros e Cecília

Helena Glanzner.

Formal analysis: Natascha Monteiro Medeiros e Cecília

Helena Glanzner.

Investigation: Natascha Monteiro Medeiros e Cecília

Helena Glanzner.

Methodology: Natascha Monteiro Medeiros e Cecília

Helena Glanzner.

Project administration: Natascha Monteiro Medeiros e

Cecília Helena Glanzner.

Supervision: Daniela Silva dos Santos Schneider e

Cecília Helena Glanzner.

Writing-original draft: Natascha Monteiro Medeiros.

Writing-review \& editing: Daniela Silva dos Santos

Schneider e Cecília Helena Glanzner.

The authors declare that there is no conflict of interest.

\section{- Corresponding author:}

Cecília Helena Glanzner

Email: glanznercecilia@gmail.com

\section{Associate editor:}

Carlise Rigon Dalla Nora 